
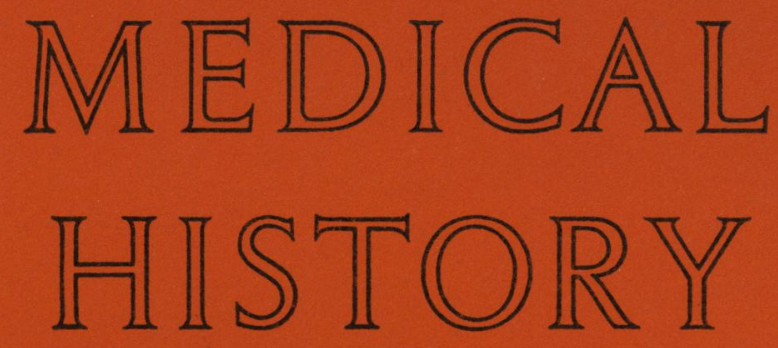

\title{
A QUARTERLY JOURNAL
}

DEVOTED TO THE HISTORY AND BIBLIOGRAPHY OF MEDICINE AND THE RELATED SAIENCES

\section{Volume XI Number 3}

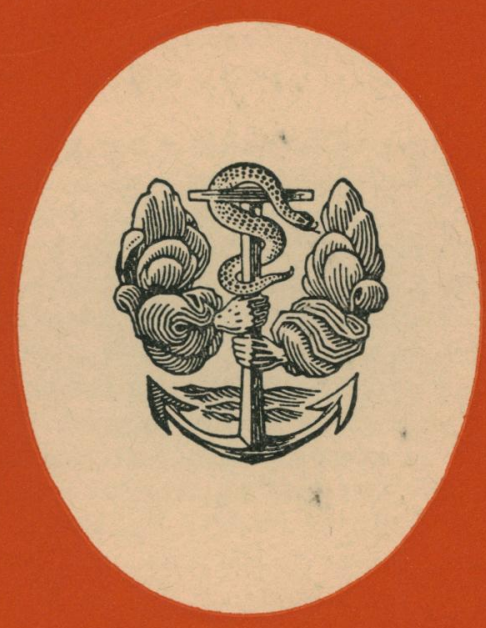

\section{JULY 1967}

THE WELLCOME HISTORICAL MEDICAL LIBRARY 


\section{CONTENTS}

Volume XI

JULY 1967

Number 3

\section{Main Articles}

PHARMACEUTICAL HISTORY AND ITS SOURCES IN THE WELLCOME COLLECTIONS: I-THE GROWTH OF PROFESSIONALISM IN NINETEENTH CENTURY

\section{BRITISH PHARMACY}

J. K. CRELLIN

Page 215
A HISTORY OF THE MEDICINAL USE OF TOBACCO 1492-1860
GRACE G. STEWART
Page 228

SIR ARCHIBALD STEVENSON, HIS ANCESTRY, AND THE RIOT IN THE COLLEGE OF PHYSICIANS AT EDINBURGH

W. B. HOWIE

Page 269

THE WARRINGTON DISPENSARY LIBRARY

R. GUEST-GORNALL

Page 285

SIR JAMES MACKENZIE: THE BURNLEY YEARS

A. E. WALES and J. SHAFAR

Page 297

THE INTRODUCTION OF HYDROCYANIC ACID INTO MEDICINE:

A STUDY IN THE HISTORY OF CLINICAL PHARMACOLOGY

MRLVIN P. EARLES

Page 305

\section{News, Notes and Queries}

Sixth Hundredth Anniversary of the Foundation of the First University of Hungary, by Balázs Bugyi.

\section{Book Reviews}

Doctors and the State: The British Medical Profession and Government Action, by Jeanne L. Brand. A History of Ideas about the Prolongation of Life: The Evolution of the Prolongevity Hypothesis to 1800, by Gerald J. Gruman. Current Problems in the History of Medicine, ed. by R. Blaser and H. Buess. Quellen zur Geschichte der Kinderheilkunde, ed. by A. Peiper. Great Moments in Medicine and Pharmacy: a History of Medicine and Pharmacy in Pictures, by G. A. Bender and R. A. Thom. 


\section{MEDICAL HISTORY}

THE OFFICIAL JOURNAL OF THE BRITISH SOCIETY FOR THE HISTORY OF MEDICINE

Editor: F. N. L. POYNTER, PH.D., F.R.S.L., F.L.A.

\section{Editorial Board:}

THE RT. HON. LORD COHEN OF BIRKENHEAD, M.D., P.R.C.P.

SIR ZACHARY COPE, M.D., M.S., F.R.C.S.

W. S. C. COPEMAN, C.B.E., M.D., F.R.C.P.

DOUGLAS GUTHRIE, M.D., F.R.C.P.(Ed.), F.R.C.s.(Ed.), F.R.s.(Ed.)

K. D. KeELE, M.D., F.R.C.P.

SIR ARTHUR MACNALTY, K.C.B., M.A., M.D., F.R.C.P., F.R.C.S.

\section{NOTICE TO CONTRIBUTORS}

Contributions, which may deal with any aspect of medical history or bibliography, are invited. The maximum length for original articles is about 10,000 words. Previously unpublished texts and documents, short papers, and bibliographical notes and queries will also be welcomed.

Manuscripts should be typewritten with double spacing and wide margins. The Editor reserves the right to make literary corrections. Captions or legends of illustrations should include particulars of their source and should be typed on a separate sheet. References should be arranged in number order, or alphabetically by author, and typewritten in double space. Each reference should contain name(s) and initial(s) of author(s) and full title of paper or work. Journal articles should also include name of journal, year, volume number, and complete pagination, in that order. Abbreviations of journal citations should conform to the style used in the World List of Scientific Periodicals. With books, the city of origin, publisher, date, and full pagination should be given.

A galley proof, which should be corrected and returned to the Editor as quickly as possible, will be sent to every contributor of an original article.

Contributors of main articles will receive fifty reprints free of cost. Particulars of the cost of additional reprints will be sent before publication, and orders for additional reprints should be made by return.

Manuscripts, review copies of books and reprints, and correspondence relating to the publication of papers should be addressed to the Editor, Medical History, The Wellcome Historical Medical Library, Wellcome Building, 183 Euston Road, London, N.W.1.

Medical History is published quarterly in the third week in January, April, July and October.

\section{SUBSCRIPTIONS}

The subscription rate is $£ 30$ s. $0 d$. a year in the United Kingdom, and $\$ 9.00$ in Canada and the U.S.A. Single issues of the current volume can be purchased at $17 \mathrm{~s} .6 \mathrm{~d}$. each, and of previous volumes at $25 s$. each. There is a special subscription rate for members of the British Society for the History of Medicine.

All inquiries regarding subscriptions, orders and advertising should be addressed to Medical History, The Wellcome Historical Medical Library, Wellcome Building, 183 Euston Road, London, N.W.1. Subscriptions may also be placed with any periodical agent. 